\title{
Uptake of Galactose and Lactose by Kluyveromyces lactis: Biochemical Characteristics and Attempted Genetical Analysis
}

\author{
By HÉLÈNE BOZE, G. MOULIN AND P. GALZY* \\ Laboratoire de Recherches de la Chaire de Génétique et Microbiologie, ENSAM-INRA, \\ Place Viala, 34060 Montpellier Cedex, France
}

(Received 6 November 1985; revised 23 July 1986)

Study of the lactose and galactose transport systems in Kluyveromyces lactis has shown that lactose uptake is by active transport. The transport system is under monogenic control and is inducible. Galactose uptake is also by active transport but the system is controlled by two genes which, in the four strains we studied, are present only in $K$. lactis CBS 2359. Galactose uptake in the other $K$. lactis strains is by a simple diffusion process.

\section{INTRODUCTION}

Several sugar transport systems in Saccharomyces cerevisiae have been studied. Glucose, fructose and mannose all enter the cell by facilitated diffusion; the transport system is constitutive (Cirillo, 1962, 1968a; Kotyk \& Janecek, 1975; Heredia et al., 1968). Galactose is also transported by facilitated diffusion, but the system requires the induction of a membrane constituent coded by the gene GAL2 (Cirillo, $1968 b$; Kou \& Cirillo, 1970; Kou et al., 1970). Only sucrose (Santos et al., 1982), maltose (Okada \& Halvorson, 1964a; Serano, 1977) and methyl $\alpha$-D-glucoside (Okada \& Halvorson, 1964a,b) are taken up by active transport. The transport of maltose is coded by four genes of the $d s f$ groups (disaccharide fermentation) (Zimmerman et al., 1973). The transport of methyl $\alpha$-D-glucoside is controlled by two genes, MGL2 and MGL4. In the absence of an inducer, the transport of methyl $\alpha$-D-glucoside is by facilitated diffusion; this system is constitutive. However, a second, active transport system operates in the presence of an inducer. The gene $M G L 2$ encodes both the constituents necessary for active transport and those for facilitated diffusion.

Few transport systems have been described for Kluyveromyces lactis. Roy \& MacQuillan (1976) and Roy (1981) have shown that glucose uptake involves an inducible non-energyrequiring transport system. The lactose transport system has also been described (Dickson \& Barr, 1983; Moulin, 1984). The characteristics of lactose permease (a saturable transport system, with an apparent $K_{\mathrm{m}}$ of $1 \cdot 2-4 \mathrm{~mm}$, temperature dependence, an accumulation of substrate inside the cells, sensitivity to metabolic inhibitors) indicate that the lactose transport system is of the active type and specific to lactose. Lactose transport is inducible by lactose and galactose and strongly repressed by glucose.

In this paper we describe the galactose transport system in $K$. lactis CBS 2359, the induction and inhibition of lactose and galactose uptake, the characteristics of the different transport systems, and an attempt to identify the relevant genes.

\section{METHODS}

Organisms and growth conditions. We obtained strains CBS 2359 (a mating type) and CBS 6315 ( $\alpha$ mating type) of $K$. lactis from the Centraalbureau voor Schimmelcultures, Delft, The Netherlands, and prepared the following mutants by ethyl methane sulphonate (EMS) treatment of strain CBS 2359 (Marin, 1984). Strain 2359-5 is deficient in galactose-1-phosphate uridyltransferase: $2359-511 \mathrm{G} 11$ is deficient in both galactose-1-phosphate uridyltransferase and galactokinase ; 2359-15 is deficient in UDPgalactose 4-epimerase. Cultures were grown on a 
synthetic medium, medium G (Galzy, 1964), containing $5 \mathrm{~g}$ carbon substrate $\mathrm{l}^{-1}$. Liquid cultures were grown in Erlenmeyer flasks filled to a tenth of their volume, and shaken at $28^{\circ} \mathrm{C}$.

Genetic techniques. The haploid strains were cultivated on solid YME medium (yeast extract, $3 \mathrm{~g} \mathrm{l}^{-1} ; \mathrm{malt}^{\mathrm{l}}$ extract, $3 \mathrm{~g} \mathrm{l}^{-1}$; peptone, $5 \mathrm{~g}^{-1}$; glucose, $10 \mathrm{~g} \mathrm{l}^{-1}$ ). Genetic crosses were by replica plating on solid ME medium (malt extract, $50 \mathrm{~g} \mathrm{l}^{-1}$ ). After 3-5 d, the asci formed were dissected and micromanipulated with a Fonbrune micromanipulator.

Measurement of sugar uptake. Cells were harvested at the end of the exponential phase, centrifuged, washed twice with distilled water, and redispersed in water to obtain a suspension of $\mathrm{OD}_{420} \simeq 4$. The assay was done at $30{ }^{\circ} \mathrm{C}$. The reaction was started by adding $1 \mu \mathrm{Ci}(37 \mathrm{kBq})\left[{ }^{14} \mathrm{C}\right]$ lactose or $\left[{ }^{14} \mathrm{C}\right.$ lgalactose to $1.6 \mathrm{ml}$ cell suspension. The concentration of lactose or galactose varied from $1 \mathrm{~mm}$ to $10 \mathrm{~mm}$, the final volume being $2.5 \mathrm{ml}$. Samples $(0.5 \mathrm{ml})$ were taken every $20 \mathrm{~s}$ for $80 \mathrm{~s}$. Under these conditions, lactose uptake was linear. The reaction was stopped by diluting the sample in $10 \mathrm{ml}$ unlabelled lactose $(10 \mathrm{mM})$ or galactose $(10 \mathrm{mM})$ at $4{ }^{\circ} \mathrm{C}$. The cells were immediately filtered through Millipore filters $(0.45 \mu \mathrm{m}$ pore size) and washed twice with the lactose or galactose solution. The filters were then dissolved with $0.5 \mathrm{ml}$ Soluene $100 ; 12 \mathrm{ml}$ scintillation liquid was added and radioactivity was determined. The chemicals used were: [D-glucose-1-14 C]lactose (Amersham); D-[1-14 C]galactose (Amersham); L- $\left[1-{ }^{14} \mathrm{C}\right]$ fucose (Amersham); $\left[{ }^{14} \mathrm{C}\right]$ methyl $\beta$-D-thiogalactopyranoside (New England Nuclear); antimycin $\mathrm{A}$ (Boehringer); 2,4-dinitrophenol and sodium azide (Merck); fucose and methyl $\beta$-D-thiogalactopyranoside (Sigma).

Optical density determination. Optical density was measured at $420 \mathrm{~nm}$ with an ELVI colorimeter; 1 unit corresponded to $1.8 \mathrm{mg}$ dry $\mathrm{wt} \mathrm{ml}^{-1}$.

\section{RESULTS}

\section{Induction of the galactose uptake system}

Galactose permease activity of $K$. lactis 2359 was measured after growth to late-exponential phase on different carbon substrates. The rate of galactose entry into the cell was measured by following the uptake of $\left[{ }^{14} \mathrm{C}\right]$ galactose $(5 \mathrm{~mm})$ during the first $2 \mathrm{~min}$ (Table 1). Three levels of activity were observed: after growth in the presence of glucose, the rate of galactose uptake remained low $\left[1 \mu \mathrm{mol}(\mathrm{g} \mathrm{dry} \mathrm{wt})^{-1} \mathrm{~min}^{-1}\right]$; after growth in the presence of lactose, glycerol plus fucose or lactic acid, the rate was 3-4 $\mu \mathrm{mol}(\mathrm{g} \text { dry wt })^{-1} \mathrm{~min}^{-1}$; after growth in the presence of galactose or glycerol, the rate was very high [10-14 $\left.\mu \mathrm{mol}(\mathrm{g} \text { dry wt })^{-1} \mathrm{~min}^{-1}\right]$. Permease activity was thus always present and therefore constitutive. The rate of uptake was highest after culture on galactose.

The activity of the galactose transport system after different methods of treatment was determined on resting cells. Cells grown on glycerol or glucose were centrifuged, washed, and transferred to galactose alone or galactose plus glucose. Cells grown on lactose or lactic acid were transferred to galactose plus lactose or galactose plus lactic acid. The uptake rate was measured as before (Fig. 1). There was always some permease activity; the uptake rate was highest in the presence of galactose alone. After culture on glucose, the cells had little activity; the presence of glucose in a medium already containing galactose prevented the maximum induction of galactose permease (Fig. $1 b$ ). Furthermore, after culture on glycerol, when the cells were placed in contact with galactose plus glucose, their activity decreased considerably with time (Fig. $1 a$ ). Growth on lactose or lactic acid similarly led to low galactose permease activity: the base-line

\section{Table 1. Uptake of galactose $(5 \mathrm{mM})$ by $K$. lactis 2359 after growth on different carbon substrates}

Each growth substrate was present at $5 \mathrm{~g}^{-1}$. Where error terms are shown, the results are means of three experiments, $\pm \mathrm{SE}$; other values are representative results.

$\begin{array}{lc}\text { Growth substrate } & \begin{array}{c}\text { Uptake rate } \\ {\left[\mu \mathrm{mol}(\mathrm{g} \text { dry wt })^{-1} \mathrm{~min}^{-1}\right]}\end{array} \\ \text { Glucose } & 1 \cdot 2 \pm 0 \cdot 2 \\ \text { Lactose } & 3 \cdot 0 \pm 0 \cdot 2 \\ \text { Glycerol + fucose } & 3 \cdot 7 \\ \text { Lactic acid } & 4 \\ \text { Glycerol } & 10 \pm 1 \cdot 2 \\ \text { Galactose } & 14 \pm 1\end{array}$




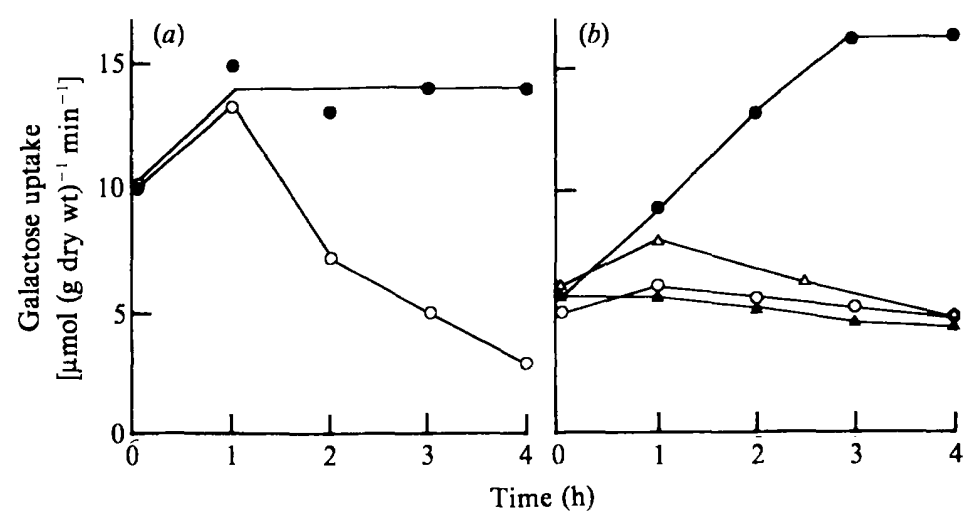

Fig. 1. Induction of galactose permease in $K$. lactis 2359. (a) After growth on glycerol, the rate of galactose uptake was measured against time with resting cells in the presence of galactose only $(O)$ or galactose + glucose $(O)$. (b) After growth on glucose $(O, \triangle)$, lactose $(O)$ or lactic acid $(\triangle)$, the rate of galactose uptake was measured against time with resting cells in the presence of galactose alone $(O)$, galactose + glucose $(\Delta)$, galactose + lactose $(O)$ or galactose + lactic acid $(\triangle)$. All growth substrates were present at $5 \mathrm{~g} \mathrm{I}^{-1}$; compounds in the uptake assay were present at $5 \mathrm{~mm}$.

Table 2. Parameters of the initial rate of galactose uptake by $K$. lactis 2359 after growth on different carbon substrates

Each growth substrate was present at $5 \mathrm{~g} \mathrm{l}^{-1}$. The results are means of three or four measurements from three or four preparations, \pm SE.

$\begin{array}{lcc}\text { Growth substrate } & \begin{array}{c}K_{\mathrm{m}} \\ (\mathrm{mM})\end{array} & \begin{array}{c}V_{\max } \\ {\left[\mu \mathrm{mol}(\mathrm{g} \mathrm{dry} \mathrm{wt})^{-1} \mathrm{~min}^{-1} \text { ] }\right.}\end{array} \\ \text { Glucose } & 10 \pm 1 \cdot 5 & 3 \pm 2 \\ \text { Lactose } & 9 \pm 3 & 8 \pm 3 \\ \text { Glycerol } & 0.9 \pm 0 \cdot 1 & 9 \pm 2 \\ \text { Glycerol + fucose } & 1 \pm 0 \cdot 1 & 5 \pm 1 \\ \text { Galactose } & 1.2 \pm 0.5 & 18 \pm 3.5\end{array}$

level increased slightly after $1 \mathrm{~h}$ of contact, then returned to the initial level (Fig. $1 b$ ). Thus glucose, lactose and lactic acid blocked the biosynthesis of the galactose transport system. Okada \& Halvorson (1964) have shown that in the same way the induction of the methyl $\alpha$-Dglucoside transport system is greatly inhibited by the presence of acetate at a concentration of $0 \cdot 1 \mathrm{M}$.

\section{Parameters of the galactose transport system}

The uptake of galactose was linear and the kinetic parameters could be estimated quite accurately within the first $2 \mathrm{~min}$. The values of $K_{\mathrm{m}}$ and $V_{\max }$ are summarized in Table 2. After growth on glycerol, galactose or glycerol plus fucose, the observed $K_{\mathrm{m}}$ was about $1 \mathrm{~mm}$. A single constitutive galactose transport system could thus be present in all these conditions. Only the maximum rate of galactose uptake differed: $V_{\max }$ was two to three times higher in the presence of galactose. However, after growth on glucose, the $K_{\mathrm{m}}$ was nearly $10 \mathrm{mM}$. This suggests that $K$. lactis 2359 may contain two different systems for galactose transport, their expression depending upon the carbon source.

\section{Influence of different sugars on galactose uptake}

We studied the influence of different carbon substrates on the rate of uptake of $\left[{ }^{14} \mathrm{C}\right]$ galactose $(5 \mathrm{mM})$ in order to determine the specificity of each transport system. Assuming that the permeases have a similar apparent $K_{\mathrm{m}}$ for other substrates as for galactose, in theory uptake would be inhibited by $50 \%$ if the substrate were used at a concentration of $5 \mathrm{mM}$, and by $91 \%$ if 
Table 3. Uptake of $\left[{ }^{14} \mathrm{Clgalactose}(5 \mathrm{~mm})\right.$ by $\mathrm{K}$. lactis 2359 measured in the presence of carbohydrates added at various concentrations after growth on different substrates

$V$ is expressed in $\mu \mathrm{mol}(\mathrm{g} \mathrm{dry} \mathrm{wt})^{-1} \min ^{-1} ; I \%$ is the percentage inhibition.

\begin{tabular}{|c|c|c|c|c|c|c|c|}
\hline \multirow{3}{*}{$\begin{array}{c}\text { Carbohydrate } \\
\text { added }\end{array}$} & \multirow{3}{*}{$\begin{array}{c}\text { Concn } \\
(\mathrm{m} \mathrm{M})\end{array}$} & \multicolumn{6}{|c|}{ Growth substrate $\left(5 \mathrm{~g} \mathrm{l}^{-1}\right)$ : } \\
\hline & & \multicolumn{2}{|c|}{ Glycerol } & \multicolumn{2}{|c|}{ Galactose } & \multicolumn{2}{|c|}{ Lactose } \\
\hline & & $V$ & $I \%$ & $V$ & $I \%$ & $V$ & $I \%$ \\
\hline Control & - & 11 & & 14 & & $3 \cdot 2$ & \\
\hline \multirow[t]{2}{*}{ Galactose } & 5 & & 50 & & 39 & & \\
\hline & 50 & & 80 & & 82 & & \\
\hline \multirow[t]{2}{*}{ Lactose } & 5 & 7 & 36 & $12 \cdot 5$ & 10 & $2 \cdot 5$ & 20 \\
\hline & 50 & 7 & 36 & $10 \cdot 5$ & 25 & $2 \cdot 6$ & 18 \\
\hline \multirow{2}{*}{$\begin{array}{l}\text { Methyl } \beta \text {-D- } \\
\text { thiogalactoside }\end{array}$} & 5 & 21 & 0 & 14 & 0 & 4 & 0 \\
\hline & 50 & 18 & 0 & 11 & 20 & $3 \cdot 5$ & 0 \\
\hline \multirow{2}{*}{$\begin{array}{l}\text { Phenyl } \beta \text {-D- } \\
\text { galactoside }\end{array}$} & 5 & 12 & 0 & 11 & 21 & 3 & 6 \\
\hline & 50 & 10 & 10 & $8 \cdot 4$ & 40 & 3 & 6 \\
\hline \multirow[t]{2}{*}{ Glucose } & 5 & $3 \cdot 6$ & 68 & 9 & 36 & $3 \cdot 5$ & 0 \\
\hline & 50 & 1 & 91 & $2 \cdot 7$ & 81 & 3.8 & 0 \\
\hline \multirow[t]{2}{*}{ Fucose } & 5 & $7 \cdot 5$ & 32 & $11 \cdot 2$ & 20 & 3.4 & 0 \\
\hline & 50 & 5 & 54 & 9 & 36 & 4 & 0 \\
\hline \multirow[t]{2}{*}{ 2-Deoxygalactose } & 5 & 6 & 45 & 14 & 0 & 5 & 0 \\
\hline & 50 & $3 \cdot 5$ & 68 & $6 \cdot 7$ & 52 & 5 & 0 \\
\hline
\end{tabular}

the substrate were used at a concentration of $50 \mathrm{~mm}$. In fact, the addition of unlabelled galactose at a concentration of $5 \mathrm{mM}$ led to a $50 \%$ decrease in uptake after growth on glycerol and $39 \%$ after growth on galactose; $50 \mathrm{~mm}$-galactose resulted in a fall of $80 \%$ after growth on glycerol or galactose (Table 3). These decreases, solely due to the dilution of $\left[{ }^{14} \mathrm{C}\right]$ galactose with the unlabelled compound, were very close to the theoretical values. Different levels of inhibition were obtained depending on the carbon substrate employed during growth (Table 3). After growth on lactose, only lactose provoked a slight inhibition (20\%) of galactose uptake. Glucose at a concentration of $5 \mathrm{~mm}$ led to $68 \%$ and $36 \%$ inhibition after growth on glycerol and galactose respectively: with a glucose concentration of $50 \mathrm{mM}$, the corresponding values were $91 \%$ and $81 \%$. These were close to the theoretical values. It appears that glucose can use the galactose transport system. The other hexoses tested also influenced the galactose uptake rate, but to a lesser extent than did glucose. The galactosides were almost without effect.

The results of this study suggest that there are two galactose transport systems in $K$. lactis 2359. The first is a low-affinity system present after growth on lactose, and to a lesser degree on glucose, galactose entry being inhibited only by lactose. This indicates that the system has no influence on galactosides other than lactose. The second is a high-affinity system present after growth on galactose and glycerol. This is not specific for galactose, and is greatly inhibited by glucose, hexoses, galactosides (notably lactose) and lactic acid.

With cells pre-grown on galactose, the glucose inhibition constant, $K_{\mathrm{i}}$, calculated according to the Lineweaver-Burk method was $1.5 \mathrm{mM}$; inhibition was competitive. $K_{\mathrm{i}}$ was thus almost equal to the apparent $K_{\mathrm{m}}$ of galactose permease, which indicates strong competition between the two substrates. Galactose permease present under such conditions also serves as a glucose carrier.

\section{Special characteristics of galactose permease}

We studied the influence of metabolic inhibitors on the rate of galactose uptake after growth on different substrates (inducers of the various transport systems) (Table 4). In every case there was a decrease in the galactose uptake rate, the percentage of inhibition varying from $70 \%$ to $90 \%$. This indicated that the two systems of transport are energy-dependent.

The uptake rates also varied with temperature. After growth on glycerol and galactose, the activation energy was $68 \mathrm{~kJ} \mathrm{~mol}^{-1}$ but after growth on lactose it was only $24 \mathrm{~kJ} \mathrm{~mol}^{-1}$.

Active transport can be distinguished from facilitated or simple diffusion by the accumulation of substrate within the cells. For this study we used $K$. lactis 2359 and two mutants, 2359-5 and 


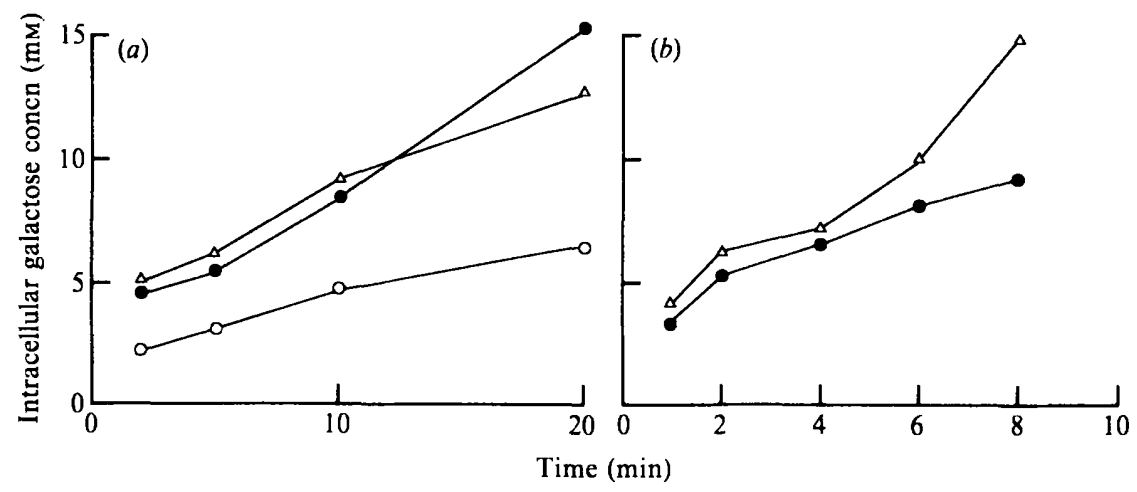

Fig. 2. Intracellular concentration of galactose in different $K$. lactis strains after growth on various media. (a) Strains 2359-5 (O), 2359-511G11 $(\triangle)$ and $2359(O)$ were grown on glycerol medium; $(b)$ strain 2359 was grown on lactose $(\odot)$ and on galactose $(\triangle)$ media. All growth substrates were present at $5 \mathrm{~g} \mathrm{I}^{-1}$. Washed cells were resuspended in $1 \mathrm{~mm}-\left[{ }^{14} \mathrm{C}\right]$ galactose and intracellular radioactivity was measured against time.

Table 4. Effect of inhibitors on galactose transport in K. lactis 2359

Cells were pre-incubated for $30 \mathrm{~min}$ in the presence of the inhibitor. The standard uptake assay, with $5 \mathrm{~mm}$-galactose, was used.

\begin{tabular}{|c|c|c|c|}
\hline \multirow[b]{2}{*}{ Inhibitor } & \multicolumn{3}{|c|}{$\begin{array}{l}\text { Percentage inhibition of transport } \\
\text { after growth on different substrates*: }\end{array}$} \\
\hline & Glycerol & Galactose & Lactose \\
\hline Iodoacetate $(0.5 \mathrm{~mm})$ & 73 & 83 & 94 \\
\hline Antimycin $(0.2 \mu \mathrm{M})$ & 91 & 83 & 92 \\
\hline Sodium azide $(0.5 \mathrm{~mm})$ & 68 & 55 & 77 \\
\hline Dinitrophenol $(0.5 \mathrm{mM})$ & 87 & 88 & 77 \\
\hline \multicolumn{4}{|c|}{${ }^{*}$ Each at $5 \mathrm{~g} \mathrm{l}^{-1}$. } \\
\hline
\end{tabular}

2359-511G1, obtained from it (Marin, 1984). Both mutants lack galactose- 1 -phosphate uridyltransferase activity; strain $2359-511 \mathrm{G} 1$ also lacks galactokinase activity. These mutants could therefore no longer use galactose as a carbon source, but galactose uptake could be measured if the cultures were grown on glycerol. On this medium, high-affinity permease was present for all three strains (Fig. $2 a$ ). In the case of $K$. lactis 2359 , measurements were made after growth on galactose, when the high-affinity permease was present, and on lactose, when the lowaffinity permease was present (Fig. $2 b$ ). Cells were harvested at the end of the exponential growth phase, centrifuged, washed and then placed in a solution of $\left[{ }^{14} \mathrm{C}\right]$ galactose $(1 \mathrm{mM})$. Intracellular radioactivity was measured between the 1 st and the 20th minute of contact time. The water fraction of the cells was measured by the method described by Conway \& Downey (1950), $1 \mathrm{mg}$ dry wt corresponding to $1 \mu \mathrm{l}$ intracellular volume. After growth on glycerol and galactose, when the high-affinity permease was present, the intracellular concentration of galactose was about 15 times higher than in the extracellular medium, whereas after growth on lactose, when the low-affinity permease was present, the increase was only ninefold. In both cases galactose entry was by active transport.

The $\mathrm{pH}$ value was of no special significance for either system. After growth on galactose at $\mathrm{pH}$ values of $4-6$ the activity was $90-100 \%$ of maximum, whilst above $\mathrm{pH} 6$ it fell by $30 \%$. After growth on lactose at $\mathrm{pH}$ values of 3-5, the activity was $96-100 \%$ of maximum, whilst above $\mathrm{pH} 5$ there was a decrease of $30-40 \%$. The $\mathrm{pH}$ for maximum activity differed by one $\mathrm{pH}$ unit between the two transport systems. 
Table 5. Phenotypes of spores obtained after crossing of K. lactis strains 2359-15 and 6315

All spores from the first two phenotypes (lines 1 and 2) differed only in permease activity. $\mathrm{E}^{+}, \mathrm{E}^{-}$ denote the presence and absence, respectively, of UDPgalactose 4-epimerase.

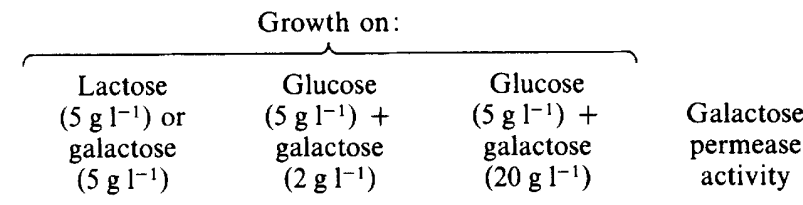

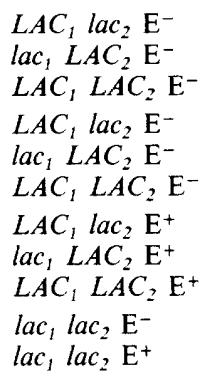

$\begin{array}{cc}- & - \\ - & + \\ + & + \\ - & \\ - & +\end{array}$

\section{Genetic studies}

The existence of two different galactose transport systems suggests that there may be a structural gene $(P H A)$ encoding the high-affinity permease and a second gene ( $P L A)$ encoding the low-affinity permease. A genetic study of this system is complicated by the existence of the two genes $L A C_{1}$ and $L A C_{2}$. At least one wild-type allele is necessary for galactose and lactose to be used. Strains with genes $l a c_{t}$ and $l a c_{2}$ cannot grow on galactose or lactose; they have no $\beta$ galactosidase, galactokinase, galactose-1-phosphate uridyltransferase, UDPgalactose epimerase, galactose permease or lactose permease (Herman \& Halvorson, 1963; Moulin, 1984). It is also difficult to interpret segregation patterns where genes conferring similar mutant phenotypes are involved.

In order to study how the two galactose transport systems segregated, we crossed $K$. lactis strain 2359-15 (a) of genotype $l a c_{1} L A C_{2}$ epimerase $^{-}$, with permease activity, with $K$. lactis strain $6315(\alpha) L A C_{1} l a c_{2}$ epimerase ${ }^{+}$, without permease activity (Table 5). Galactose is toxic for epimerase galactokinase $^{+}$cells because it accumulates in the form of galactose 1-phosphate or UDPgalactose (Sheets \& Dickson, 1980; Douglas \& Hawthorne, 1964). Under these conditions the addition of galactose $\left(20 \mathrm{~g}^{-1}\right)$ to a solid medium containing glucose $\left(5 \mathrm{~g}^{-1}\right)$ inhibits the growth of these strains. On the other hand, the addition of galactose at a low concentration $\left(2 \mathrm{~g}^{-1}\right)$ inhibits only the growth of strains with galactose permease activity. When crossing different strains of $K$. lactis, three genes which influence growth in the presence of galactose have to be considered. Two of them, $l a c_{1}$ and $l a c_{2}$, would influence simultaneously not only permease activity, but also the activity of the structural genes of the two permeases. The disjunction of the five gene couples which, for various reasons, intervene on the same phenotype is not realistic. We therefore only studied spores from the first two phenotypes described in Table 5. In the 20 asci examined, 17 spores were of the first phenotype and had permease activity, whilst 17 other spores belonged to the second phenotype and had no permease activity. All the spores examined were $L A C_{1}$ and/or $L A C_{2}$, therefore the absence of permease activity can only be linked to the inactivity of the galactose permease structural genes. On the other hand, galactose permease activity could be due to the presence of one or two active genes. In the absence of a link, the segregation of two independent genes should produce a $3: 41: 4$ segregation type. It is therefore surprising that a $1: 21: 2$ type of segregation was actually observed in spores in which epimerase, $L A C_{1}, L A C_{2}$ genes cannot, in theory, interfere with permease activity.

We then crossed $K$. lactis strain 2359 (a) of genotype $l a c_{1}, L A C_{2}$, with permease activity, with 
Table 6. $O D_{420}$ values after $24 \mathrm{~h}$ growth on galactose at different concentrations for strains with $\left(P^{+}\right)$or without $\left(P^{-}\right)$galactose permease

$\begin{array}{crccc}\text { Strain } & \begin{array}{c}\text { Galactose } \\ \text { concn }\left(\mathrm{g} \mathrm{l}^{-1}\right) \ldots 1\end{array} & 2 & 5 & 10 \\ \text { K. lactis } 2359\left(\mathrm{P}^{+}\right) & 0.35 & 0.63 & 0.95 & 1.4 \\ \text { K. lactis } 6315\left(\mathrm{P}^{-}\right) & 0.19 & 0.36 & 0.45 & 1.0\end{array}$

$K$. lactis strain $6315(\alpha)$ of genotype $L A C_{1}$, lac 2 , without permease activity. Here again the cross was designed to determine how the two galactose transport systems segregated. Since both strains were epimerase ${ }^{+}$, one gene less was involved. We dissected and studied nine different asci. Optical density measurements were made after $24 \mathrm{~h}$ growth on galactose at $1 \mathrm{~g} \mathrm{t}^{-1}$ and $2 \mathrm{~g} \mathrm{l}^{-1}$, and the uptake rate of $\left[{ }^{14} \mathrm{C}\right] \mathrm{galactose}(1 \mathrm{~mm})$ was measured after growth on galactose and lactose. Douglas \& Condie (1954) observed that $S$. cerevisiae mutants ( $\mathrm{gal}$ ) deficient in galactose permease grew only in the presence of a high concentration of galactose. Goldenthal et al. (1983) showed that the same phenomenon exists for maltose-permease-deficient mutants of $S$. cerevisiae. As shown by Moulin (1984), the growth rate of $K$. lactis strain 6315, having no galactose permease, was dependent on the galactose concentration in the medium, and the maximum $\mathrm{OD}_{420}$ measured after $24 \mathrm{~h}$ growth was less than that for strain 2359 , which possesses galactose permease (Table 6). Spores that yielded cultures of $\mathrm{OD}_{420} \leqslant 0 \cdot 19$ after $24 \mathrm{~h}$ growth on galactose at $1 \mathrm{~g} \mathrm{l}^{-1}$, and $\mathrm{OD}_{420} \leqslant 0.36$ after $24 \mathrm{~h}$ growth on galactose at $2 \mathrm{~g} \mathrm{l}^{-1}$, were classed as being deficient in galactose permease $\left(\mathrm{P}^{-}\right)$. Spores that yielded cultures of $\mathrm{OD}_{420} \geqslant 0.35$ after $24 \mathrm{~h}$ growth on galactose at $1 \mathrm{~g} \mathrm{l}^{-1}$, and $\mathrm{OD}_{420} \geqslant 0.63$ after $24 \mathrm{~h}$ growth on galactose at $2 \mathrm{~g} \mathrm{l}^{-1}$, were classed as having a galactose permease system $\left(\mathrm{P}^{+}\right)$.

The rate of uptake of $\left[{ }^{14} \mathrm{C}\right]$ galactose was measured after the spores had been grown on galactose and lactose. With $\mathrm{P}^{+}$spores, permease activity was measurable. The uptake rates were three to five times higher after growth on galactose than on lactose. No permease activity was detected in $\mathrm{P}^{-}$spores.

We obtained samples of four types of asci of the following phenotypes: $\mathrm{P}^{+} \mathbf{P}^{+} \mathbf{P}^{-} \mathbf{P}^{-}$(one ascus), $\mathrm{P}^{-} \mathrm{P}^{+} \mathrm{P}^{+} 0$ (five asci), $\mathrm{P}^{-} \mathrm{P}^{+} 00$ (one ascus) and $\mathrm{P}^{+} \mathrm{P}^{+} 00$ (two asci) $\left(\mathrm{P}^{+}\right.$denotes presence of permease, $\mathrm{P}^{-}$denotes lack of permease, and 0 denotes lack of permease caused by the presence of $l a c_{1}$ and $\left.l a c_{2}\right)$. Among these nine asci, we were able to use only one for genetic studies into the characteristics of galactose permease, because the other eight had $l a c_{1}, l a c_{2}$ spores, which prevented us from obtaining any information. We therefore studied this particular ascus more closely. After growth on galactose, one spore was found to possess a galactose permease of $K_{\mathrm{m}}=1 \mathrm{mM}$ (PHA); another had a galactose permease with $K_{\mathrm{m}}=10 \mathrm{~mm}$ (PLA); the other two spores had no activity. After growth on lactose the first two spores had a galactose permease activity of $K_{\mathrm{m}}=10 \mathrm{mM}$. The other two still had no galactose permease activity. These results show clearly that there can be genetic recombination of the PHA ${ }^{+}$and $\mathrm{PLA}^{+}$characters. This is sufficient to eliminate any hypothesis that the two types of permease activity studied could be controlled by a single gene with one allele giving phenotype $\mathrm{PHA}^{+} \mathrm{PLA}^{+}$for $K$. lactis strain 2359, and another allele giving phenotype $\mathrm{PHA}^{-} \mathrm{PLA}^{-}$for $K$. lactis strain 6315 . These results indicate that one gene couple, $P \mathrm{HA}^{+} / \mathrm{PHA}^{-}$, codes high-affinity permease and another, $P L A^{+} / P L A^{-}$, codes low-affinity permease. However, the segregation observed in the two crosses differed from that expected during the segregation of two gene couples having no physical linkage or physiological relationship.

The model proposed is based on the fact that although two genes must be involved, we observed a $2: 2$ rather than a $3: 1$ segregation of galactose permease activity in the first cross. Table 7 shows the types of asci expected if one gene couple were epistatic on the other, the $\mathrm{PHA}^{+}$gene being active only in the presence of the $P L A^{+}$gene, and inactive in the presence of the $P L A^{-}$gene. The completely analysed ascus would be a tetratype. The results observed from the two crosses confirm this hypothesis. Control by one gene couple only can be excluded, since genetic recombination took place. The possibility of linkage between the two loci cannot be excluded, but this alone will not explain all the experimental results. 


\section{Table 7. Segregation of the genes PLA and PHA}

The table shows the phenotypes of asci expected according to the following hypothesis. $P L A^{+} \operatorname{codes}$ for a galactose permease which is always present whatever the growth substrate $\left(K_{m}=10 \mathrm{mM}\right) . P H A^{+}$ codes for a galactose permease present after culture on glycerol and galactose but repressed by glucose and lactose; $\mathrm{PH} \mathrm{A}^{+}$operates only when associated with $P L A^{+}$. In this case, an active permease with $K_{m}$ $=1 \mathrm{~mm}$ is obtained. $K$. lactis 2359 would be $P L A^{+} P H A^{+}$, and $K$. lactis 6315 would be $P L A^{-} P H A^{-}$.

\begin{tabular}{|c|c|c|c|}
\hline & $\begin{array}{l}\mathrm{PLA}^{+} \mathrm{PHA}^{+} \\
\mathrm{PLA}^{+} \mathrm{PHA}^{+} \\
\mathrm{PLA}^{-} \mathrm{PHA}^{-} \\
\text {PLA }^{-} \mathrm{PHA}^{-}\end{array}$ & $\begin{array}{l}\mathrm{PLA}^{+} \mathrm{PHA}^{+} \\
\mathrm{PLA}^{+} \mathrm{PHA}^{-} \\
\mathrm{PLA}^{-} \mathrm{PHA}^{+} \\
\mathrm{PLA}^{-} \mathrm{PHA}^{-}\end{array}$ & $\begin{array}{l}\mathrm{PLA}^{+} \mathrm{PHA}^{-} \\
\mathrm{PLA}^{+} \mathrm{PHA}^{-} \\
\mathrm{PLA}^{-} \mathrm{PHA}^{+} \\
\mathrm{PLA}^{-} \mathrm{PHA}^{+}\end{array}$ \\
\hline Ascus type* & PD & TT & NDP \\
\hline $\begin{array}{l}\text { Phenotype after } \\
\text { culture on } \\
\text { galactose }\end{array}$ & $\begin{array}{l}+\left(K_{\mathrm{m}}=1\right) \\
+\left(K_{\mathrm{m}}=1\right) \\
-\end{array}$ & $\begin{array}{l}+\left(K_{\mathrm{m}}=1\right) \\
+\left(K_{\mathrm{m}}=10\right) \\
-\end{array}$ & $\begin{array}{l}+\left(K_{\mathrm{m}}=10\right) \\
+\left(K_{\mathrm{m}}=10\right) \\
-\end{array}$ \\
\hline $\begin{array}{l}\text { Phenotype after } \\
\text { culture on } \\
\text { lactose }\end{array}$ & $\begin{array}{l}+\left(K_{\mathrm{m}}=10\right) \\
+\left(K_{\mathrm{m}}=10\right) \\
-\end{array}$ & $\begin{array}{l}+\left(K_{\mathrm{m}}=10\right) \\
+\left(K_{\mathrm{m}}=10\right) \\
-\end{array}$ & $\begin{array}{l}+\left(K_{\mathrm{m}}=10\right) \\
+\left(K_{\mathrm{m}}=10\right) \\
-\end{array}$ \\
\hline
\end{tabular}

*PD, parental ditype; TT, tetratype; NDP, non-parental ditype.

Lactose permease of $K$. lactis strain 2359

The lactose transport system of $K$. lactis 6315 has been described by Moulin (1984), and that of $K$. lactis 1140 and its mutants by Dickson \& Barr (1983). The active transport of lactose by $K$. lactis 2359 had similar characteristics to that of $K$. lactis 6315 . The apparent $K_{\mathrm{m}}$ was $2 \mathrm{~mm}$ and the maximum uptake rate $\left(V_{\max }\right)$ was $26 \mu \mathrm{mol}(\mathrm{g} \text { dry wt })^{-1} \mathrm{~min}^{-1}$ in the presence of lactose or galactose inducer substrates. Lactose permease was also present after growth on glycerol, although the maximum uptake rate remained low $\left[9 \mu \mathrm{mol}(\mathrm{g} \mathrm{dry} \mathrm{wt})^{-1} \mathrm{~min}^{-1}\right]$; its biosynthesis was greatly repressed by glucose. It was specific for lactose, none of the sugars tested (glucose, galactose, fucose, methyl $\beta$-D-thiogalactoside) having any influence on the rate of entry. The lactose permease was sensitive to metabolic inhibitors and therefore energy-dependent. Lactose could concentrate to a level 10 times higher within the cell than outside it. We are therefore dealing with an active transport system.

Genetic control studies of the lactose permease system were done using strains obtained from the crossing of $K$. lactis strains 2359 and 6315 , both of which possess lactose carriers. Nine asci were micromanipulated and 36 spores analysed. Thirteen spores were of genotype $l a c_{1} l a c_{2}$ and could not metabolize lactose; all the others had a lactose permease. We were unable to obtain lactose-permease-negative recombinants. It appears that the permeases in the two strains are encoded by a single gene.

\section{DISCUSSION}

Our results show that two galactose transport systems exist in $K$. lactis 2359 . The first, a lowaffinity system, appears to be present whatever substrate is used and is specific for galactose; it is an active transport system. The second system has a higher affinity for galactose (apparent $K_{\mathrm{m}}=1 \mathrm{~mm}$ ). It is strongly repressed by glucose and certain other substrates, including lactose and lactic acid, and is not specific for galactose.

On the basis of our findings, we now propose a hypothesis concerning the presence and function of the different genes which encode these transport systems. One gene (PLA), always active, codes a constituent necessary for the two permeases. A second gene $(P H A)$ is expressed only in the presence of galactose and glycerol; it is repressed by glucose, lactose and lactic acid. The association or simultaneous presence of two products encoded by both $P L A$ and $P H A$ is necessary for the second system to function. The gene $P H A$ alone would have little influence. A 
model similar to this has been described in $S$. cerevisiae for the transport of methyl $\alpha$-D-glucoside (Okada \& Halvorson, 1964a). It should be noted that we found galactose permeases only in $K$. lactis 2359. In the three other $K$. lactis strains we studied (strains 6315, Y11630 and Y11631), no galactose transport system was found. However, galactose was metabolized, entry into the cell being by a simple diffusion process.

The results presented here show the extreme complexity and heterogeneity of the transport system, even within a given species of yeast. Among all the strains of $K$. lactis studied, only one lactose permease was found. On the other hand, we found two different galactose permeases within a single strain, in spite of the fact that the other strains possessed no galactose permease.

\section{REFERENCES}

CIRILLO, V.P. (1962). Mechanisms of glucose transport across the yeast cell membrane. Journal of Bacteriology 84, 485-491.

CirILLO, V. P. (1968a). Relationship between sugar structure and competition for the sugar transport system in baker's yeast. Journal of Bacteriology 95 , 603-611.

CiRILlo, V. P. (1968b). Galactose transport in Saccharomyces cerevisiae. I. Non-metabolized sugars as substrates and inducers of the galactose transport system. Journal of Bacteriology 95, 1721-1731.

Conway, E. J. \& Downey, M. (1950). An outer metabolic region of the yeast cell. Biochemistry 47 , 347-355.

DICKSON, R. C. \& BARR, K. (1983). Characterization of lactose transport in Kluyveromyces lactis. Journal of Bacteriology 154, 1245-1253.

Douglas, H. C. \& Condie, F. (1954). The genetic control of galactose utilization in Saccharomyces. Journal of Bacteriology 68, 662-670.

Douglas, H. C. \& Hawthorne, D. C. (1964). Enzymatic expression and genetic linkage of genes controlling galactose utilization in Saccharomyces. Genetics 19, 837-844.

Galzy, P. (1964). Etude génétique et physiologique du métabolisme de l'acide lactique chez Saccharomyces cerevisiae Hansen. Annales de technologie agricole 13, $109-259$.

Goldenthal, M. J., Cohen, J. D. \& Marmur, J. (1983). Isolation and characterization of a maltose transport mutant in the yeast Saccharomyces cerevisiae. Current Genetics 7, 195-199.

Heredia, C. F., Sols, A. \& de la Fuente, G. (1968). Specificity of the constitutive hexose transport in yeast. European Journal of Biochemistry 5, 321-329.

HERMAN, A. \& Hal vorson, J. (1963). Identification of the structural gene for $\beta$-glucosidase in Saccharomyces lactis. Journal of Bacteriology 85, 895-900.

KoTyK, A. \& JANECEK, K. (1975). Cell Membrane Transport, p. 341. New York: Plenum Press.

Kou, S. C. \& Cirillo, V. P. (1970). Galactose transport in Saccharomyces cerevisiae. III. Characteristics of galactose uptake in transferaseless cells: evidence against transport associated phosphorylation. Journal of Bacteriology 103, 679-685.
Kou, S. C., Christensen, M. S. \& Cirillo, V. P. (1970). Galactose transport in Saccharomyces cerevisiae. II. Characteristics of galactose uptake and exchange in galactokinaseless cells. Journal of Bacteriology 103, 671-678.

Marin, M. H. (1984). Étude de l'amélioration génétique de mutants 'galactose négatif' chez Kluyveromyces lactis en vue de la production de galactose. Thèse 3ème cycle, USTL Montpellier.

Moulin, G. (1984). Physiologie et génétique des Kluyveromyces. Utilisation pour la valorisation du lactosérum. Thèse d'Etat, USTL Montpellier.

OKADA, H. \& Halvorson, H. O. (1964a). Uptake of $\alpha-$ thioethyl D-glucopyranoside by Saccharomyces cerevisiae. I. The genetic control of facilitated diffusion and active transport. Biochimica et biophysica acta $\mathbf{8 2}$, 538-546.

OKaDA, H. \& Halvorson, H. O. (1964b). Uptake of $\alpha$ thioethyl D-glucopyranoside by Saccharomyces cerevisiae. II. General characteristics of an active transport system. Biochimica et biophysica acta $\mathbf{8 2}$, 547-555.

RoY, P. W. (1981). Facilitated diffusion of 6-deoxy-Dglucose by the oxidative yeast Kluyveromyces lactis. Archives of Microbiology 130, 87-89.

Roy, P. W. \& MacQuillan, A. M. (1976). Evidence for an inducible glucose transport in Kluyveromyces lactis. Biochimica et biophysica acta 426, 302-316.

Santos, E. L., Rodriguez, L., Elorza, M. V. \& SENTANDREU, R. (1982). Uptake of sucrose transport by Saccharomyces cerevisiae. Archives of Biochemistry and Biophysics 216, 652-660.

SERANo, R. (1977). Energy requirements for maltose transport in yeast. European Journal of Biochemistry 80, 97-102.

SheETs, R. M. \& Dickson, R. C. (1980). Mutation affecting synthesis of $\beta$-galactosidase activity in yeast Kluyveromyces lactis. Genetics 95, 877-890.

ZimmermanN, F. K., Khan, N. A. \& Eaton, N. R. (1973). Identification of new genes involved in disaccharide fermentation in yeast. Molecular and General Genetics 123, 29-41. 